\title{
小型化トリガ機構を備えた正圧駆動式オーバーフロー防止弁
}

\author{
水野 毅*1, 石野 裕二*2, 高㠃 正也*3
}

\section{Positive-pressure driven overflow-prevention valve with compact trigger mechanism}

\author{
Takeshi MIZUNO ${ }^{* 1}$, Yuji ISHINO*2 and Masaya TAKASAKI*3 \\ ${ }^{*_{1}, * 3}$ Saitama University Graduate School of Science and Engineering \\ 255 Shimo-okubo, Sakura-ku, Saitama, 338-8570, Japan \\ ${ }^{*}$ Saitama University department of Mechanical Engineering \\ 255 Shimo-okubo, Sakura-ku, Saitama 338-8570, Japan
}

Received: 8 December 2016; Revised: 2 April 2017; Accepted: 30 April 2017

\begin{abstract}
A new over-flow prevention valve with a trigger mechanism is designed, fabricated and studied experimentally to evaluate its performances. Loading arms are used to transfer combustible fluid such as oil between tankers and tanks. A loading arm is equipped with an over-flow prevention valve for safety. This valve stops the fluid flow when the fluid exceeds a threshold level in a tank. It must be composed of mechanical elements solely because electric components may induce combustion. Therefore, it uses a pneumatic circuit to detect the fluid level and close the valve. The fabricated valve utilizes positive pressure caused by the height difference of fluid level between the tank and the sensor probe instead of negative pressure that was used in a conventional valve. However, the positive pressure is insufficient to close the valve directly. Therefore, a trigger mechanism is introduced between a piston pushed by the positive pressure and a locking mechanism keeping the valve open. This mechanism generates sufficient force to release the lock and close the main valve from the force pushing the piston. The concept, operation principles and the pneumatic circuit design are presented. Experiments simulating actual operation are carried out with the fabricated valve. The sensor probe is inserted into the water with a constant speed by a single-axis robot instead of flowing oil into the tank. The relation between the velocity and the depth when the valve closes are studied experimentally.
\end{abstract}

Key words : Oil and air hydraulics, Pneumatic equipment, Material handling equipment, Valve

\section{1. 緒言}

石油などの可燃性液体を港湾や油槽所とタンカーやタンクローリなどとの間で荷役するローディングアームに は, タンクの容量を超えて積込みしないようにするため, 図 1 のような緊急回避用のオーバーフロー防止弁が備 わっている.これは可燃性液体を扱うため, タンク内の液面検出用のセンサや主弁を閉じるためのアクチュエー 夕に電気を利用するものを使用することができない，そのため，機械的要素だけで液面検出と主弁を閉じる必要 がある. オーバーフロー防止弁は, 主にセンサプローブ, エアシリンダ, ロック機構, 主弁によって構成される. センサプローブは空気が出入りできる開口部であり，エアシリンダに接続されている．この開口部が液面によっ て塞がれることによって液面高さを検出する．このセンサプローブには，フロート（うき）のような機構は，可 動部品がタンク内で脱落する危険性があるので，使用できない，ロック機構は，操作レバーなどによって主弁を 開いた状態を保持寸る機構である. エアシリンダのピストンは, センサプローブの圧力と大気圧の差から, 閉弁 のためロック機構を解除する力を発生する.このピストン両室の圧力差を発生させる方法としては, 液体の流れ とベンチュリ効果により発生する負圧を利用する方法，外部からエアを供給しその供給圧力を利用する方法，夕

No.16-00558 [DOI:10.1299/transjsme.16-00558], J-STAGE Advance Publication date: 15 May, 2017

${ }^{* 1}$ 正員, フェロー，埼玉大学理工学研究科（广338-8570 埼玉県さいたま市桜区下大久保 255）

*2 正員, 埼玉大学工学部機械工学科

*3 正員, 埼玉大学理工学研究科

E-mail of corresponding author: yishino@mech.saitama-u.ac.jp 
ンク内の液面とセンサプローブ内部の液面差により発生する正圧を利用した方法が実用化されている.

開発の基となったオーバーフロー防止弁の写真と構造を図 2 に示す(油機工業株式会社 accessed on 10, March, 2016). これは負圧を利用している. この方法では発生する負圧が作動流体の流速に依存するため, 流量が少なく なると緊急時に動作しない問題がある. そのため, 絞り部の開口面積を小さくすると流速が速くなり, 下限動作 流量が少なくなるが，管路と流体との間の摩擦による火災の危険があるため，できる限り流速は遅くするほうが 望ましい(K, Minne, 1957),(木下，1965). 図で示されるオーバーフロー防止弁は, 流路の直径が 3 5[inch] (80 127[mm])用で, 下限動作流量を少なくし, さらにロック機構を解除するために必要な力を得るため, シリン ダの外側直径が 300[mm]と, 流路よりもかなり大きくなっている.

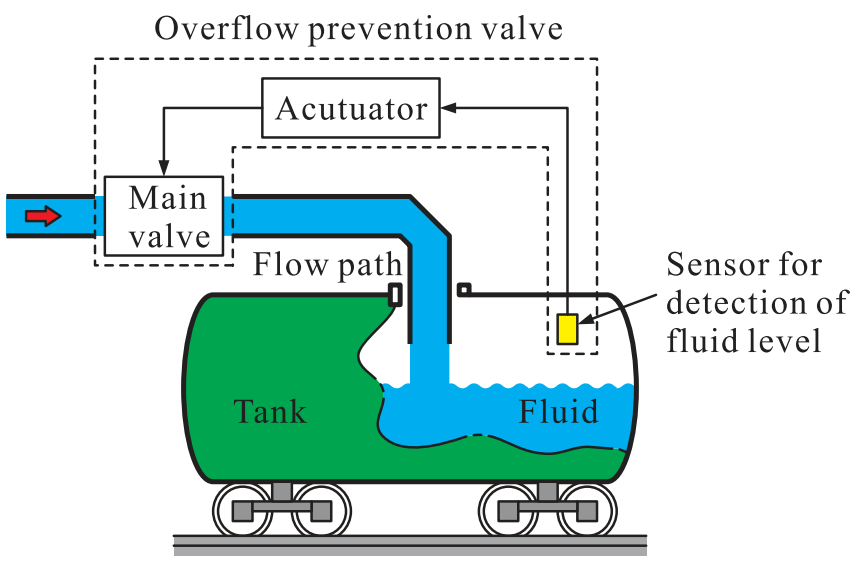

Fig. 1 Schematic view of an overflow-prevention valve using in supplying for a tank track. The overflow-prevention valve stops the fluid flow when the fluid exceeds a threshold level in a tank. The valve consists of a flow path, a main valve, a sensor for detecting the fluid level in the tank and an actuator for shutting the main valve.

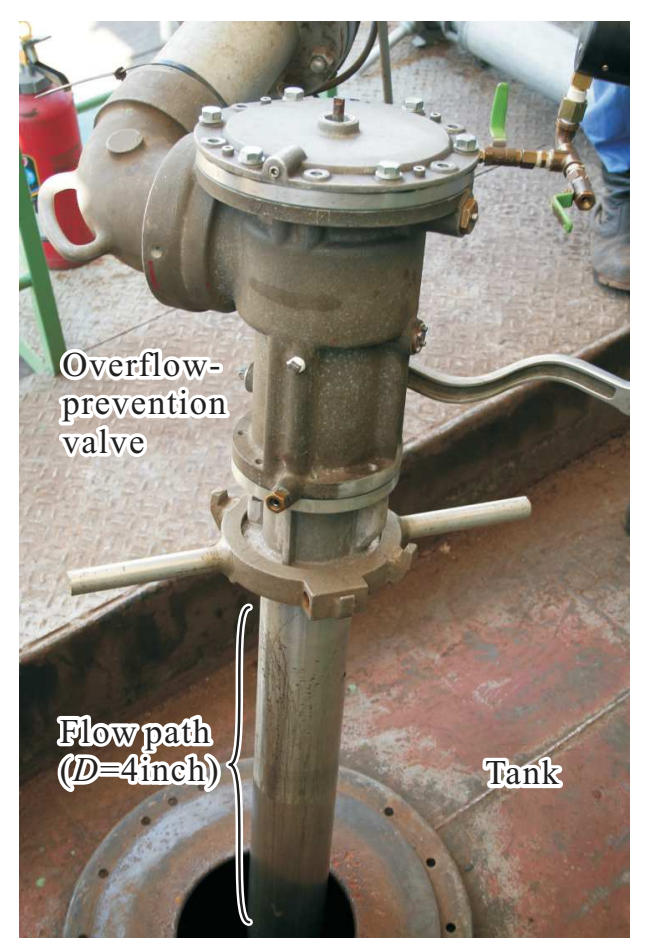

(a) Photograph of a loading arm

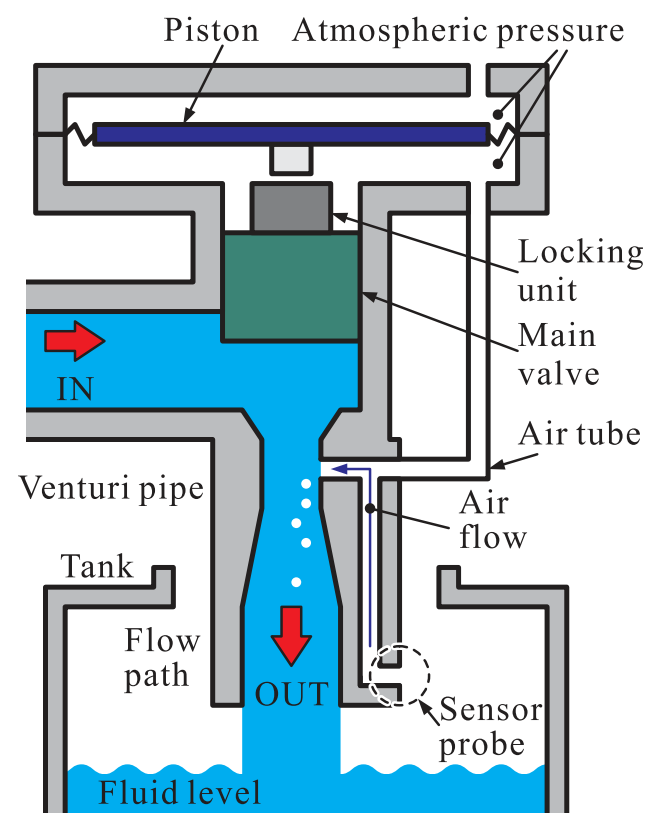

(b) Model of a conventional overflow-prevention valve

Fig. 2 Photograph (a) and schematic view (b) of a loading arm with an overflow-prevention valve for combustible fluid. The fluid flows through a main valve and a Venturi pipe. A locking unit maintains an open state of the main valve. The pressure in a sensor probe connected to an inner chamber decreases when the fluid level exceeds an aperture area of the sensor probe. The piston generates force releasing the locking unit for the main valve. 
外部からエアを供給する方法では，空気圧源にコンプレッサを用いることが多い．この場合は流量が少なくて も動作しない問題は生じない，しかしコンプレッサを動か寸ために，電源が必要となるため，可燃性流体を扱う 流路から離れた場所にコンプレッサを設置する必要があり, 設備・運転コストが上昇することがデメリットであ る.

正圧を用いる方法も流速に依存しないため，動作流量は少なくても問題はない．しかし，主弁を閉じるだけの 力を得るために，センサプローブの開口部をタンク液面よりも深く差し込み，その断面積も大きくする必要があ る. 通常，センサプローブは管路と一体の構造となっている．そのためセンサプローブの断面積を大きくすると 流路が相対的に小さくなってしまう.さらに, センサプローブ開口部とタンク液面の差（以降, 挿入深さという) を大きく寸ると, 管路自体をタンク内に深く挿入しなければならないので, バルブの重量増加の原因となり, 作 業時の負担になる.

そこで，正圧を利用したオーバーフロー防止弁の問題を解決するため, 空気圧ピストンとロック機構の間に永 久磁石の横ずれ力を利用したトリガ機構を挿入したオーバーフロー防止弁を提案し, その試作を行った(千田 他, 2015). このトリガ機構とは, 小さな入力によって, 主弁を閉じるために必要な大きな出力を得る機構である. 試 作したオーバーフロー防止弁は，正圧を利用しているため下限動作流量が存在せず，また挿入したトリガ機構に よりピストンが発生する必要な力が小さくて済むので, センサプローブの断面積と挿入深さ及び, ピストンの直 径も小さく寸ることができた．しかしながら試作したトリガ機構は，永久磁石の横ずれ力と板ばねの復元力を用 いていたため, かなり大きな装置となっていた，そこで本研究では，特殊な形状をした強磁性体からなる可動子 と, 永久磁石に生じる横ずれ力と吸引力を用いることにより，ピストン直径が従来のものと比べて $1 / 2$ となるオ ーバーフロー防止弁を開発する。

\section{2. トリガ機構を備えたオーバーフロー防止弁}

\section{$2 \cdot 1$ 正圧を用いたオーバーフロー防止弁}

図 3 に提案するオーバーフロー防止弁のモデルを示す(水野 他, 2014),(Y. Ishino et al., 2016). 図 3 (a)に主弁が開

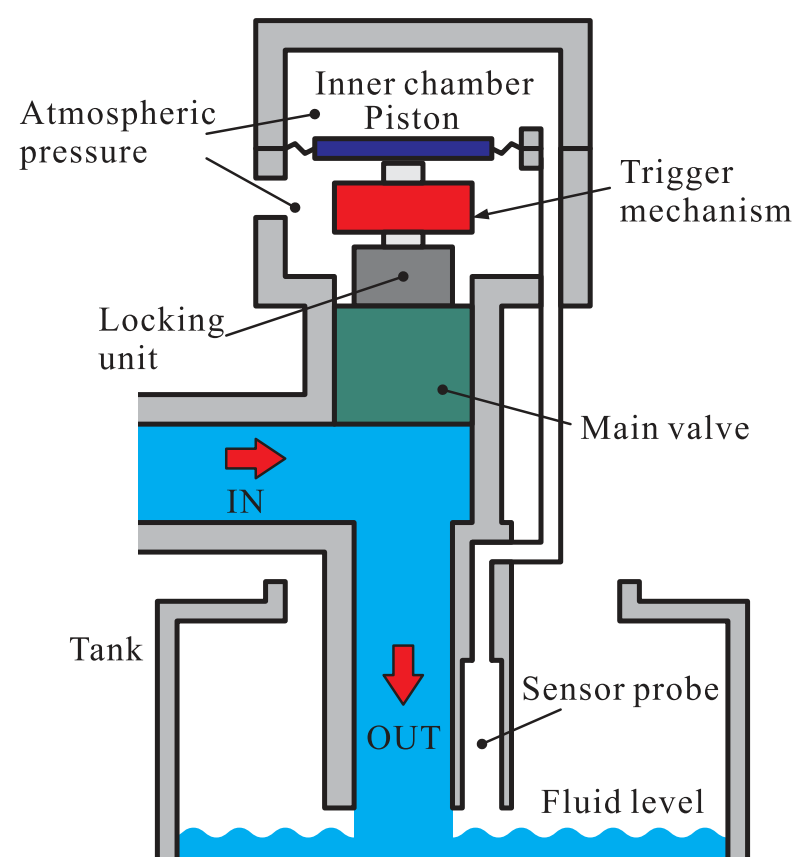

(a) Open state

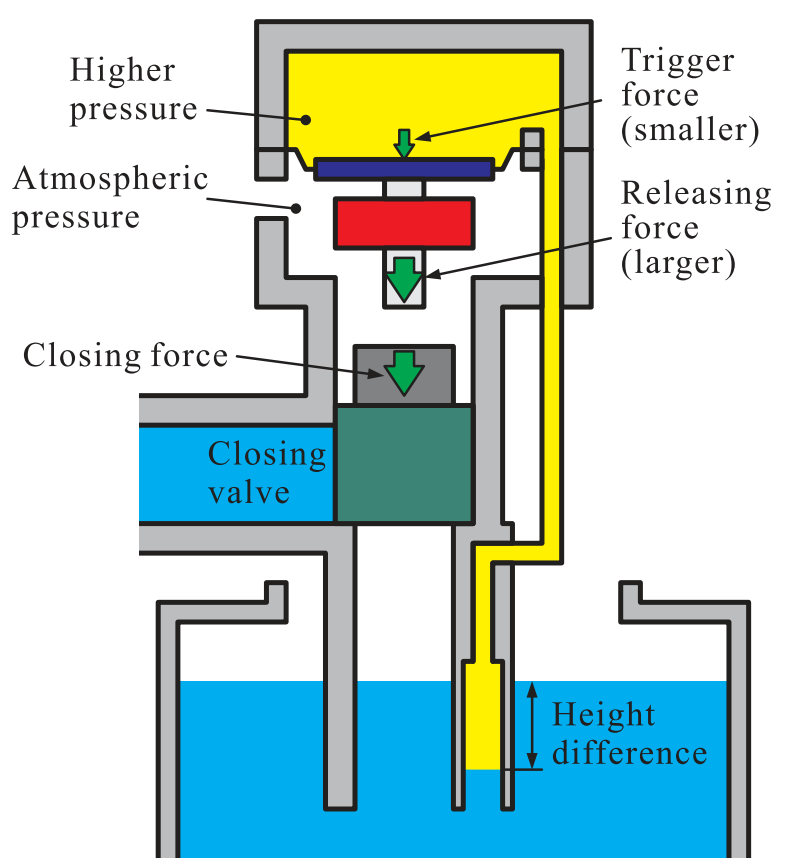

(b) Closed state

Fig. 3 Schematic views of a proposed overflow-prevention valve with a trigger mechanism using positive pressure in the open state (a) and the closed state (b). The proposed valve inserts the trigger mechanism between the piston and the locking unit. The pressure of the inner chamber increases due to the height difference between the tank and the sensor probe. The piston generates trigger force by the pressure difference. The trigger mechanism produces a sufficient force to release the locking unit when the trigger force exceeds a threshold level. 
いている状態, 図 3 (b)にオーバーフロー検知後に閉弁した状態を示す.オーバーフロー防止弁は, センサプロー ブ，ピストン，ロック機構，トリガ機構及び主弁によって構成されている．開弁状態では，図 3 (a)の図中左側か ら可燃性流体が流入し，下向きに流出する。このときセンサプローブの開口部が作動流体によって塞がれていな い状態となっているため，ピストン両室は共に大気圧となっている．タンク内の流体液面がセンサプローブの開 口部よりも高くなると，センサプローブに接続されたピストンの一室の圧力は，センサプローブとタンク内部の 液面差により，大気圧よりも高くなる．またピストンが変位するとその容積を埋めるように，センサプローブ内 に流体が流入する. 図 3 (b)の閉弁時のセンサプローブの挿入深さは，これらの高さの和になる．ピストンによっ て直接ロック機構を解除するために必要な力と変位を得るためには, 大きな挿入深さと断面積が必要となる. 提 案する方法ではピストンとロック機構の間にトリガ機構を挿入し，ピストンが発生する小さな力と変位からロッ ク機構を解除するために十分な力・変位を得る. そのため, センサプローブの挿入深さと断面積を小さくするこ とが可能である.

\section{$2 \cdot 2$ ロック機構}

図 4 にロック機構のモデルを示す. 図 3 と同様に図 4 (a)に開弁時, 図 4 (b)に閉弁時を示す. ロック機構は主軸 とボール，ボールガイド，段付きカップ，上下のばねによって構成されている．ボールガイドは，ボールが図中 左右方向のみ動くように拘束している. 主軸には溝があり, 開弁状態ではボールが溝部分にはまり, 段付きカッ プの細径部分とボールガイドによって押さえられている. 図中上側のばねは段付きカップの自重を支えている. 下側のばねは, 自然長より縮んでいるので, 下向きの力がかかっているが，ロック機構によって，主弁の開放状 態が保たれている. ピストンとトリガ機構により下向きの力が作用して，段付きカップが下向きに変位すると， 図 4 (b)のようにボールが外側に変位し, ロックが外れた状態（解除）になるので, 下側のばねの力によって, 主 軸は図中下側に変位し，主弁が閉じる．このロック機構を解除するためには段付きカップを押しこむための変位 と，上側のばね力とボールなどの摺動部の摩擦力以上の入力が必要となる.

\section{$2 \cdot 3$ トリガ機構の導入}

提案するピストンとロック機構の間に挿入するトリガ機構を図 5 に示す. 図 5 (a)に開弁時, 図 5 (b)に閉弁時の 状態を示寸.トリガ機構は, 図の中心に可動子（強磁性体）があり, 固定側に取り付けられた永久磁石による吸 引力が作用している．可動子の動きは上下方向のみに動けるように拘束されており，リミッタによって可動子の 動きが制限されている. 図 5 (a)の状態では, 永久磁石と下フランジ間の上向きの吸引力と上フランジの下向きの 吸引力の差が，可動子中央の凸型の形状をした部分に作用する永久磁石の横ずれ方向の力と重力の合力より大き いので, 可動子は上方に引き上げられて下側リミッタに接触している. 上部に取り付けられたピストンによって

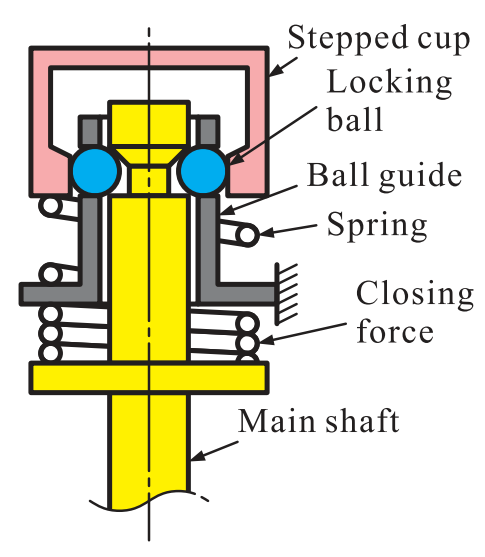

(a) Open state (Storing)

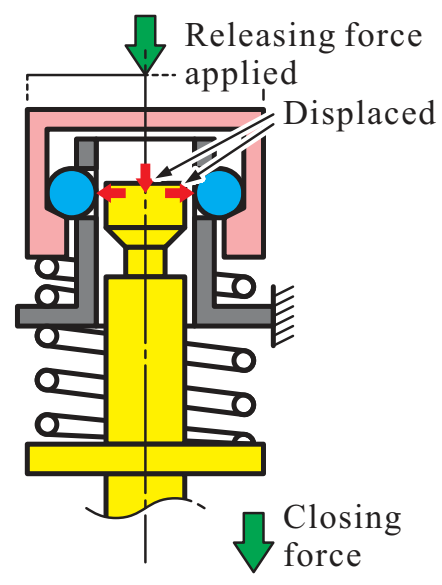

(b) Closed state (Releasing)

Fig. 4 Schematic views of the locking unit in the open state (a) and the closed state (b). A main shaft receives downward force by a compressed spring. The main shaft is supported by locking balls and a stepped cup in the open state. The locking balls displace to the outer when releasing force is applied to the stepped cup. Then the main shaft moves downward by the released force to the closed state. 
可動子にさらに下向きの力が作用するようになると，上向きの力よりも下向きの合力が大きくなり，可動子は下 向きに変位する. 永久磁石の吸引力はギャップが大きくなると小さくなるため, 下フランジを吸引する力は小さ くなり, 下向きの力が大きくなって, 可動子はさらに下向きに変位する. そして最終的に可動子が上側のリミッ 夕に接触するまで移動することとなる. このとき可動子の形状, 永久磁石の吸引力やサイズ，リミッタの位置を 適切に設定すると，ピストンからの入力が小さくても，可動子に作用する下向きの力を大きくすることができる ため，ロック機構を解除するために十分な出力を発生することができる.

\section{3. ロック機構とトリガ機構のカ測定}

開発の基となったバルブのロック機構を解除するための力と変位, 及びトリガ機構の力と, 変位を測定した. これらを測定するために図 6 に示す測定装置を製作した．この装置では，力の測定にはロードセル，変位の測定

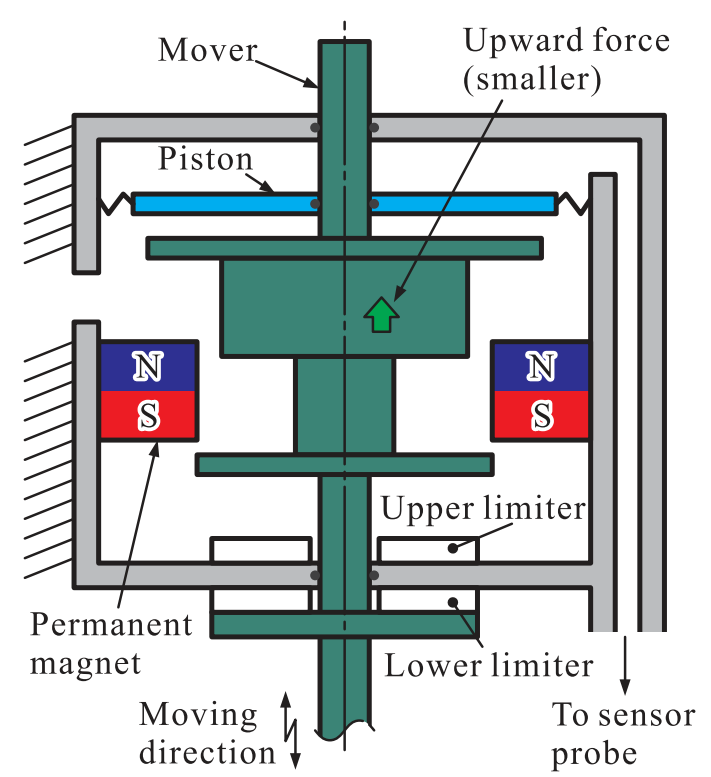

(a) Open state

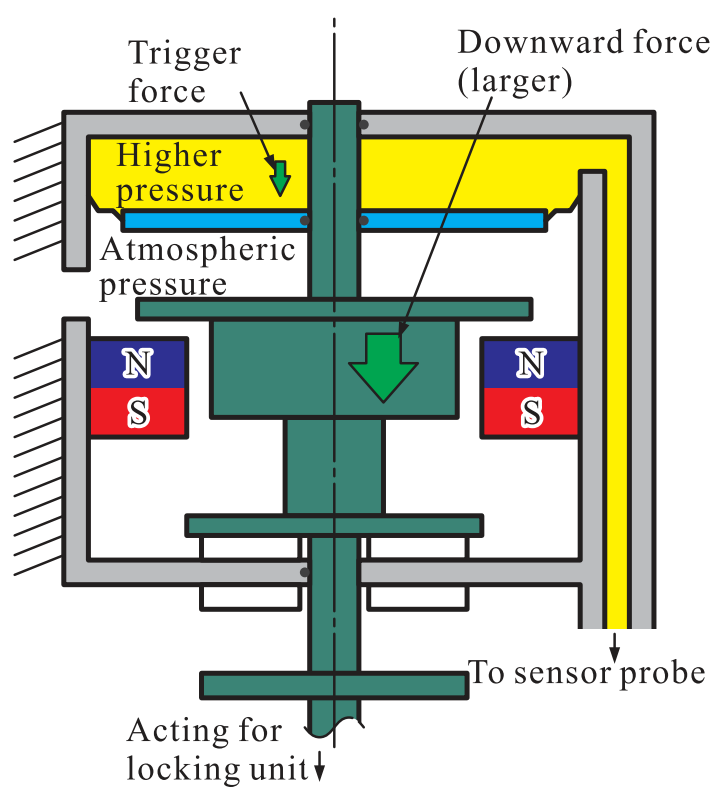

(b) Closed state

Fig. 5 Schematic views of a trigger mechanism using magnetic forces in the open state (a) and the closed state (b). Attractive and lateral forces of a permanent magnet act on a mover made of ferromagnetic material. The mover contacts the lower limiter when the upward force for the mover is larger than downward forces (open sate). The downward force consists of the magnetic attractive force acting on upper flange, the magnetic lateral force acting on the mover, and the gravitational force of the mover in the initial state. The downward force increases as the height difference increases. The mover moves downward when the downward force exceeds the upward contacted force. Then the mover reaches the closed state to contact the upper limiter.

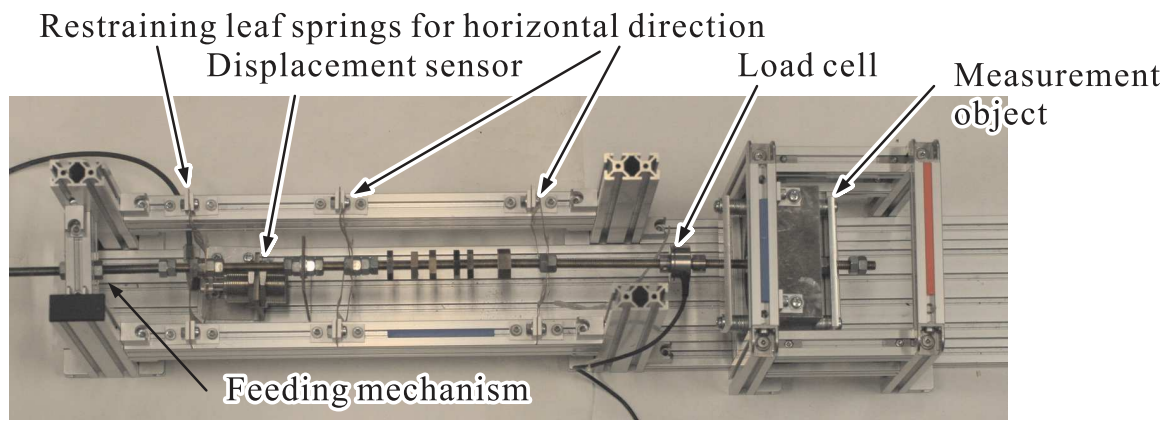

Fig. 6 Photograph of an apparatus for measuring the relation between displacement and acting force. The displacement of the mover is adjusted by a feeding mechanism. The displacement is measured by an inductive sensor, and the attractive force is measured by a load cell. The motion of the measuring object is limited to horizontal-single-axis translation by three leaf springs. 
には渦電流式変位センサを用いた. 可動子は 3 枚の板ばねによって図中横方向だけに動くように拘束されている. 可動子横方向の変位は送り機構によって与えている. 図 7 に実験結果とトリガ機構の有限要素法による磁気解析 の結果を示す．横軸は変位を表し，可動子が下側リミッタに接している状態を 0 とし，下向きの変位を正として いる. 縦軸は上向きの力を正としており, 可動子に作用する永久磁石の吸引力と横ずれ力, 可動子の重力を含む 值である. 赤丸はトリガ機構の実験值である. リミッタに接している位置で折れ曲がっている理由は, リミッタ に弾性があるためそのばね性によるためである．青丸は FEM によるトリガ機構の解析值である．緑四角はロッ ク機構の実験值である. 閉弁寸るためには, ロック機構の值を超える力と変位が必要となる. ロック機構は 22[N] 以上の入力と $3[\mathrm{~mm}]$ 以上の変位があれば閉弁する. 開弁状態では, トリガ機構の可動子が下側リミッタに $9[\mathrm{~N}]$ の 上向きの力で押しつけられている. 可動子がその力に抗して下向きに $1.8[\mathrm{~mm}]$ 変位すると, 可動子に働く合力が 上向きから下向きに切り替わる. そのためピストンによって $9[\mathrm{~N}]$ の出力と $1.8[\mathrm{~mm}]$ の変位をトリガ機構に与えれ ば，下向きに最大 $50[\mathrm{~N}]$ の出力と $9[\mathrm{~mm}]$ の変位を得ることができる. 寸なわち図に示されているトリガ機構の変 位と力の曲線が， ロック機構の変位と力曲線を常に下側にあるので，ピストンの発生力によってロック機構は解 除され，閉弁することとなる．このときトリガ機構の変位に対して下向きのカがロック機構のプロファイルを常 に超えているため, 直接ロック機構を解除寸る力と変位よりも小さな力と変位で閉弁できる.

\section{4. 空気圧回路の設計}

\section{$4 \cdot 1$ 空気圧回路の設計式の導出}

前章より得られた結果に基づいて, 空気圧回路の設計を行う. 図 8 に解析モデルを示寸. 扱う空気の圧力差が 小さいため, 空気の圧縮性を無視している. 可燃性流体の密度は製品の種類によって大きく異なるが，ガソリン の密度が 720 760[ $\left.\mathrm{kg} / \mathrm{m}^{3}\right]$ なので 750[ $\left.\mathrm{kg} / \mathrm{m}^{3}\right]$ と想定している．ピストンの上側空気室の圧力は，タンクとセンサプ ローブ内部の液面差から次式のように求められる.

$$
p_{d}=z_{1} \rho g
$$

ここで,

$p_{d} \quad:$ ピストン上側空気室のゲージ圧

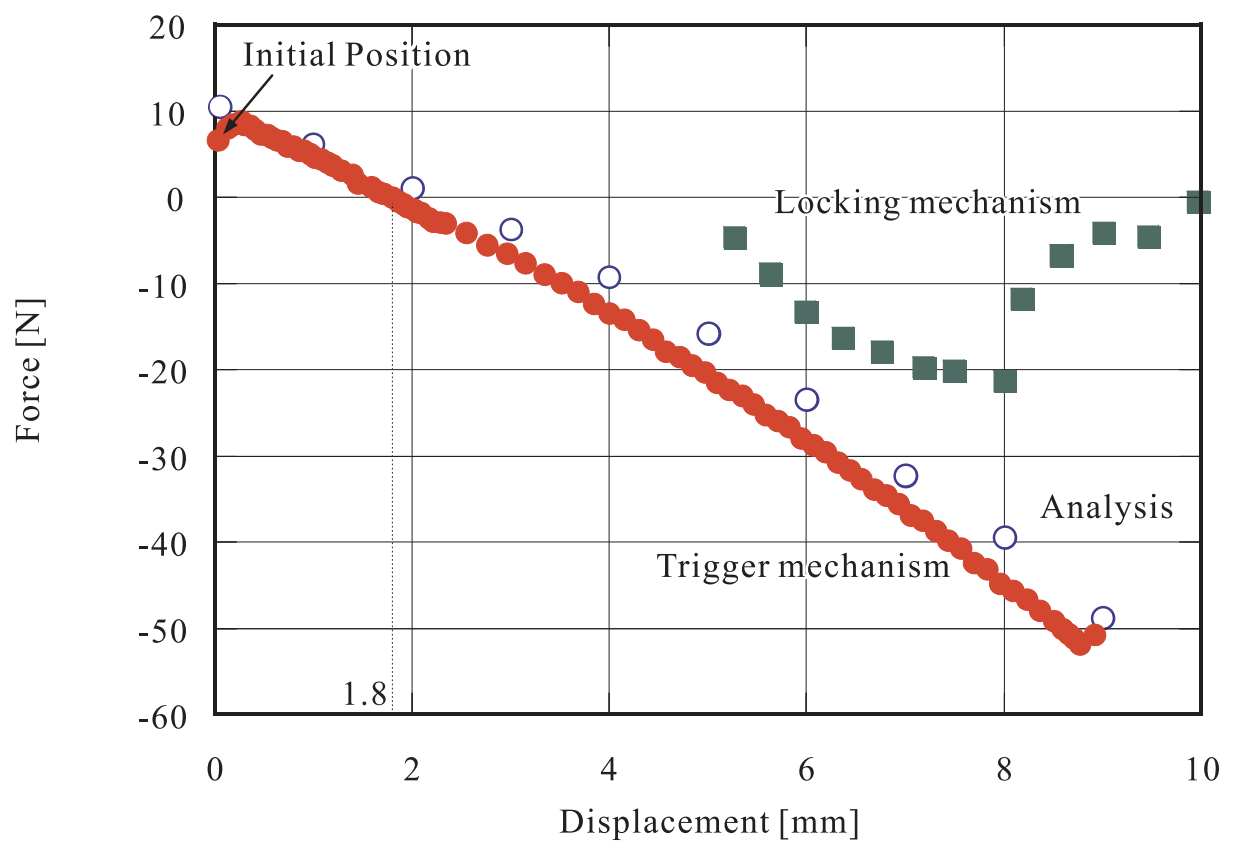

Fig. 7 Relation between the acting force and the displacement of the mover. The red dots represent the measured characteristics of the mover. The blue dots represent the results obtained by an FEM analysis. These results include the effect of the weight of the mover. The green squares represent the measured characteristics of the locking mechanism. The contacted force of the mover to the lower limiter is $9[\mathrm{~N}]$ in the open state. 
$z_{1} \quad$ : タンクとセンサプローブ内の液面差

$\rho \quad$ : 液体の密度 $\left(=750\left[\mathrm{~kg} / \mathrm{m}^{3}\right]\right)$

$g \quad$ : 重力加速度 $\left(=9.8\left[\mathrm{~m} / \mathrm{s}^{2}\right]\right)$

実験で用いたシリンダはダイヤフラム式のシリンダである. ピストン，O リングとシリンダチューブの間に発 生する摩擦力とダイヤフラムの変形による復元力を無視すると, ピストンの発生力は圧力差によって次式のよう に表せる.

$$
F_{s}=A_{s} p_{d}
$$

ここで,

$F_{s} \quad:$ ピストン出力

$A_{s} \quad$ : ピストンの有効断面積

ピストンが変位すると, 次式のように, その行程容積と同じ体積の流体がセンサプローブ内に流入する.

$$
V_{s}=A_{s} l_{s}=A_{p} z_{2}
$$

$$
\begin{array}{cl}
\text { ここで, } & \\
V_{s} & : \text { ピストンの行程容量 } \\
l_{s} & : \text { ピストンの行程 } \\
z_{2} & : \text { センサプローブ内に流入した液体の高さ } \\
A_{p} & : \text { センサプローブの断面積 }
\end{array}
$$

センサプローブのタンクに挿入する深さは, タンク内とセンサプローブ内の液面差とセンサプローブ内に流入し た液体の高さの和であるので，以上の式をまとめると，次式のように表される.

$$
z_{d}=\frac{F_{s}}{A_{s} \rho g}+\frac{A_{s} l_{s}}{A_{p}}
$$

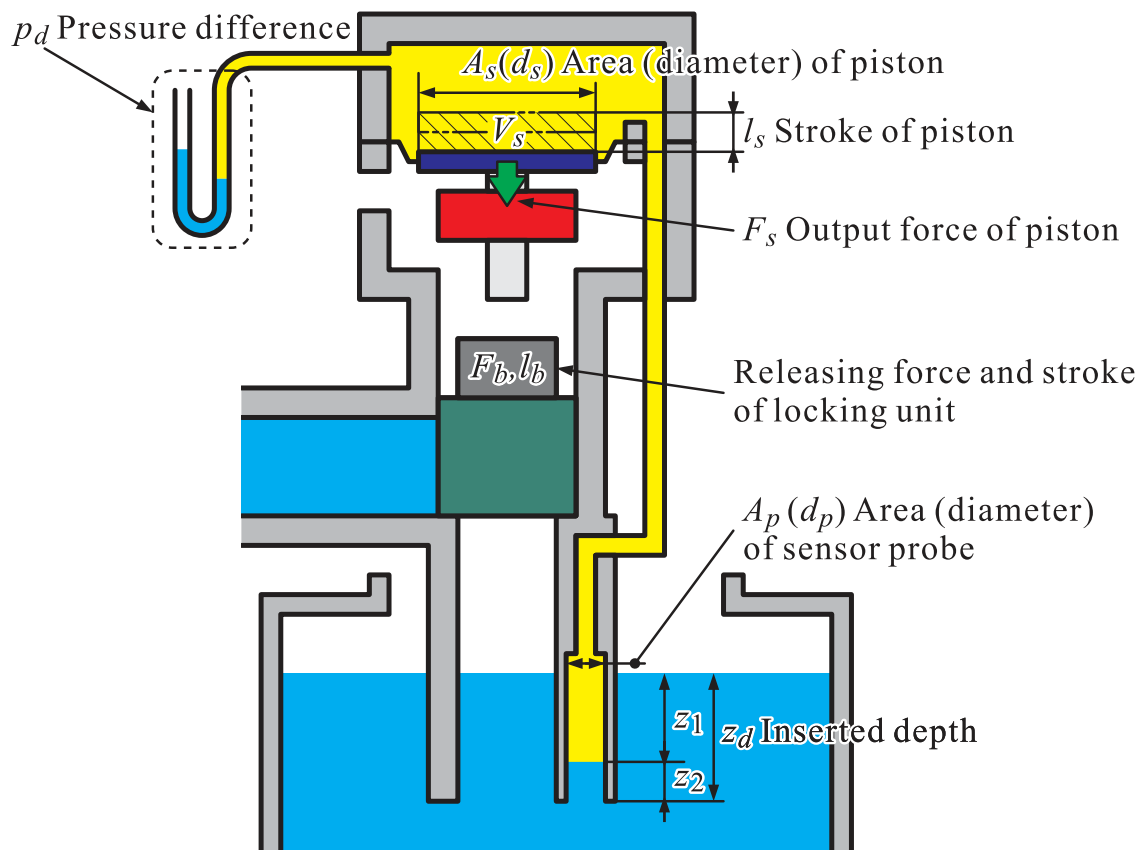

Fig. 8 Analysis model of a pneumatic circuit. The required inserted depth of the sensor probe $z_{d}$ is the sum of a height for producing height-difference pressure in the inner chamber $z_{1}$ and a height for the stroke volume of the piston $z_{2}$. 
$z_{d} \quad$ : センサプローブの挿入深さ

また，参考のため図には以下の記号も用いている.

$d_{s} \quad$ : ピストンの直径

$d_{p} \quad$ : センサプローブの直径

$F_{b} \quad$ : ロック機構を解除するために必要な力 $(=22[\mathrm{~N}])$

$l_{b} \quad$ : ロック機構を解除するために必要な変位 $(>3[\mathrm{~mm}])$

センサプローブとピストンの直径は，式(4)に基づいて決められる.

\section{4 -2 センサプローブ直径の決定}

ここでは，式(4)よりセンサプローブ直径を決める．図 9 にピストン径を $100,125,150[\mathrm{~mm}]$ とし，直接ロック機 構を解除に必要な 22[N]の出力, $3[\mathrm{~mm}]$ の変位を発生させる場合と, 図 7 の結果より求めたトリガ機構を用いた場 合の值である $9[\mathrm{~N}], 1.8[\mathrm{~mm}]$ を発生させる場合の, センサプローブの直径に対するセンサプローブの挿入深さを 示す. この図に示されるように，センサプローブの直径を小さくしすぎると，センサプローブを深く挿入しなけ ればならない，必要な挿入深さが増すと管路が長くなり，質量が増加して作業者の負担が増えてしまうため，実 用的ではない. センサプローブの直径を大きくすればセンサプローブの挿入深さを浅くすることができるが，セ ンサプローブの直径が大きくすると相対的に, 液体を供給する管路が細くなるため, あまり大きくしすぎること も実用的ではない. よって作業者の負担にならないようにプローブの挿入深さを $200[\mathrm{~mm}]$ 以下となるように決定 した.これらのことから，プローブの内径を $19[\mathrm{~mm}]$ とすることにした.

\section{$4 \cdot 3$ ピストン直径の決定}

プローブの径を $19[\mathrm{~mm}]$ として, 直接ロック機構を解除するための出力と変位, トリガ機構を用いた場合の出力 と変位を得るための，ピストン直径に対するセンサプローブの挿入深さの計算結果を図 10 に示す. 式(4)ではピ ストンの直径は右辺第 1 項及び第 2 項に分母と分子にあるため，センサプローブ挿入深さには極小值を持つよう になる.この結果から，トリガ機構を挿入した場合，プローブ挿入深さを $200[\mathrm{~mm}]$ 以下として，閉弁に必要な出 力と変位を得ることができるピストン直径の範囲は 103 171 $[\mathrm{mm}]$ である.ピストン直径もできる限り小さいほう が作業者の負担が軽減される．そのためピストンの直径を $125[\mathrm{~mm}]$ とした．また摩擦の影響をできるだけ小さく

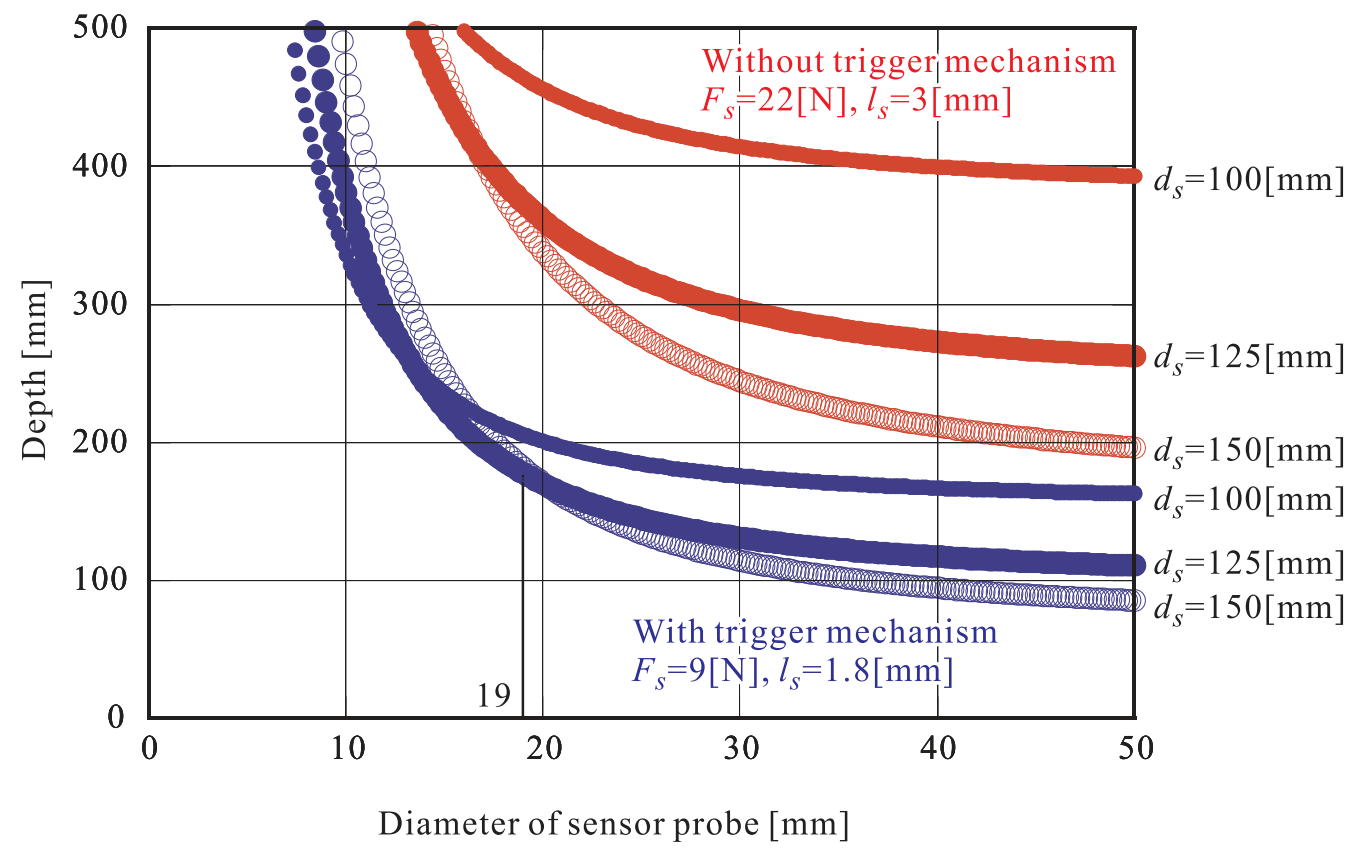

Fig. 9 Relation between the inserted depth and the diameter of the sensor probe. Red plots represent calculated values without the trigger mechanism, and blue plots represent the calculated values with the trigger mechanism. The value of $d_{s}$ represents the diameter of the piston. 
するためベロフラムシリンダとした。

\section{5. 実験装置}

図 11 に試作したトリガ機構の写真を示す.これにはピストンも含まれている. 従来のオーバーフロー防止弁の シリンダ外径が約 300[mm]であったのに対し，試作したシリンダ部を含むトリガ機構は外径が 170[mm]と約 55\% となっている. 厚みは, 開発の基となったオーバーフロー防止弁に取り付けるためと実験のしやすさから 91[mm] と大きくした．なお，実用化する場合には，この厚みを減らすことができる．図 12 に実験装置と実験構成の写真 を示す．実験装置では，オーバーフロー防止弁に試作したトリガ機構を搭載している．また本来であればオ一バ 一フロー防止弁下部より可燃性流体が吐出され，センサプローブも吐出口付近に設置される。ここでは実験のし やすさからセンサプローブを単軸ロボットに取り付け, タンク内にあらかじめ溜めた作動流体に挿入している. 単軸ロボットには液面差を測定するための超音波式の変位センサが取り付けられている。また閉弁状態を確認す るために，トリガ機構上部に変位センサを搭載している。これらの変位センサは，実験に用い実際の場面では必

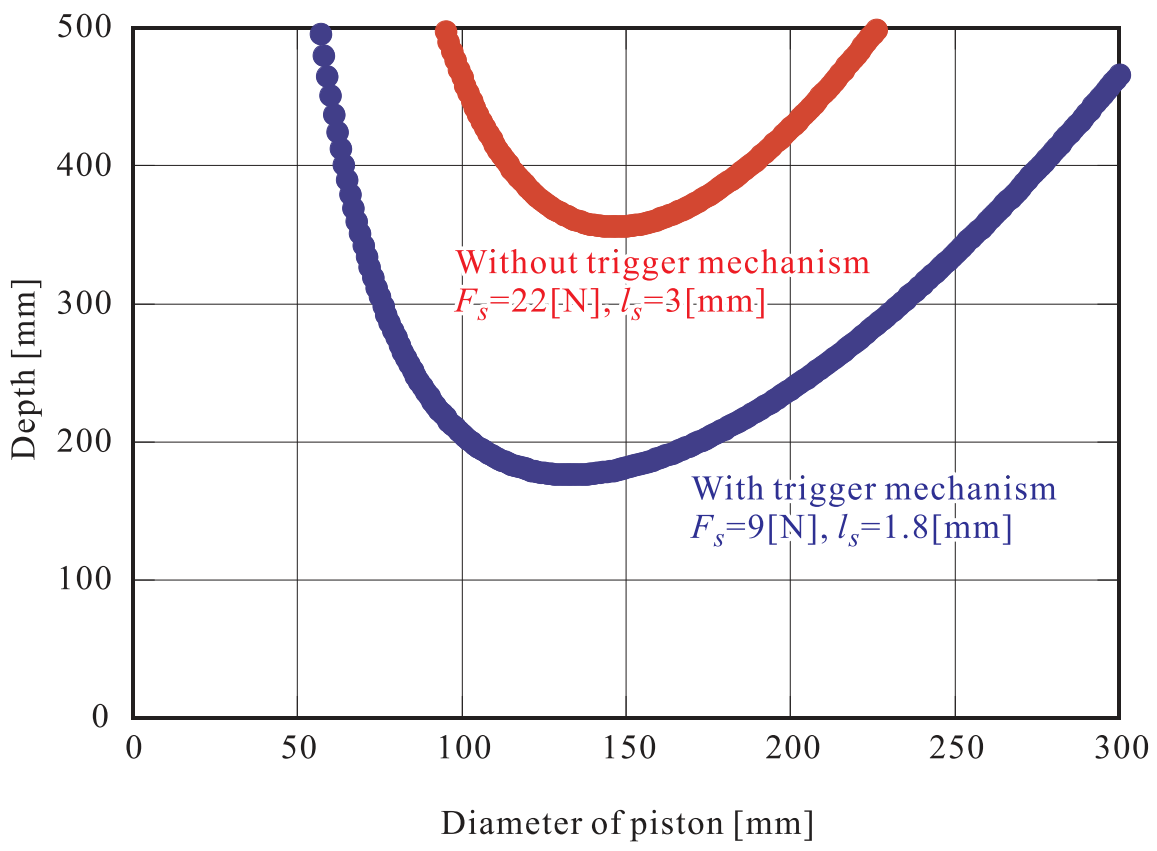

Fig. 10 Relation between the inserted depth and the diameter of the piston. Red plots represent calculated values without the trigger mechanism, and blue plots represent the calculated values with the trigger mechanism.

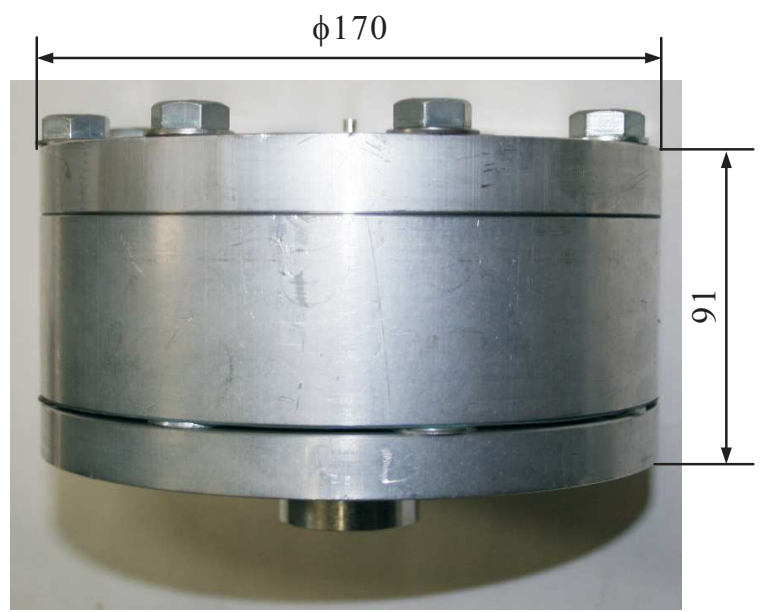

Fig. 11 Photograph of a fabricated trigger mechanism including the piston. The trigger mechanism was designed based on the previous calculations. 
要としない．また実験のしやすさと安全性から，作動流体には水を用いている．そのため水の密度より 150[mm] 程度のセンサプローブ挿入深さで閉弁動作すると予想される．実験の結果，閉弁動作が確認された。

\section{6. 実験結果}

実際に油槽所やタンクローリで使用される場合, そのタンク形状などによって油面の上昇速度は一定ではない. 開発の基となったローディングアームは最大流量が $120[\mathrm{k} \ell / \mathrm{h}]$ であり，一般的な $2[\mathrm{k} \ell]$ のタンクローリに荷役を 行った場合では $10[\mathrm{~mm} / \mathrm{s}]$ 程度の液面上昇速度である. 本実験装置ではそれよりも速い液面上昇速度を模擬するこ とが可能である．そこで 4 120[mm/s]の液面上昇速度を模擬し，センサプローブを液面に挿入する速度の影響を 調べた，センサプローブを挿入速度と，挿入深さの関係を図 13 に示寸.これはそれぞれの速度で 20 回の平均値 である. また図 14 に挿入速度 $4,40,120[\mathrm{~mm} / \mathrm{s}]$ の度数分布図を示寸. 実際の荷役での液面上昇速度では, セン サプローブの挿入深さが $150[\mathrm{~mm}]$ 程度となる. 式(4)より密度を $1000\left[\mathrm{~kg} / \mathrm{m}^{3}\right]$ として導き出される值は $153[\mathrm{~mm}]$ と, これと近い值となる. そのため可燃性流体の密度 $750\left[\mathrm{~kg} / \mathrm{m}^{3}\right]$ では $180[\mathrm{~mm}]$ 程度の挿入深さが必要であると推定さ れる. センサプローブの挿入速度が上がると挿入深さは深くなる傾向があるが，機構部分の遅れによる影響であ ると考えられる．また挿入速度が上昇するとばらつきもおおきくなる傾向が見られるが，これはセンサプローブ を液面に挿入する際に液面が乱れるためであると考えられる.

\section{7. まとめ}

可然性流体の荷役に用いられるオーバーフロー防止弁の改良を行った，オーバーフロー防止弁は液面差によっ て生じる正圧を利用している．従来のオーバーフロー防止弁は，荷役流体によって生じる負圧を利用しているた め，動作する下限の流速があり，またシリンダ部が大きくする必要があった．正圧を利用することで流速の制約 はなくなったが, 主弁を閉じるための力を発生できないので, トリガ機構を導入した. このトリガ機構は, 9[N], $1.8[\mathrm{~mm}]$ の小さな入力によって $50[\mathrm{~N}], 9[\mathrm{~mm}]$ の大きな出力を発生することができる. この機構を挿入することに

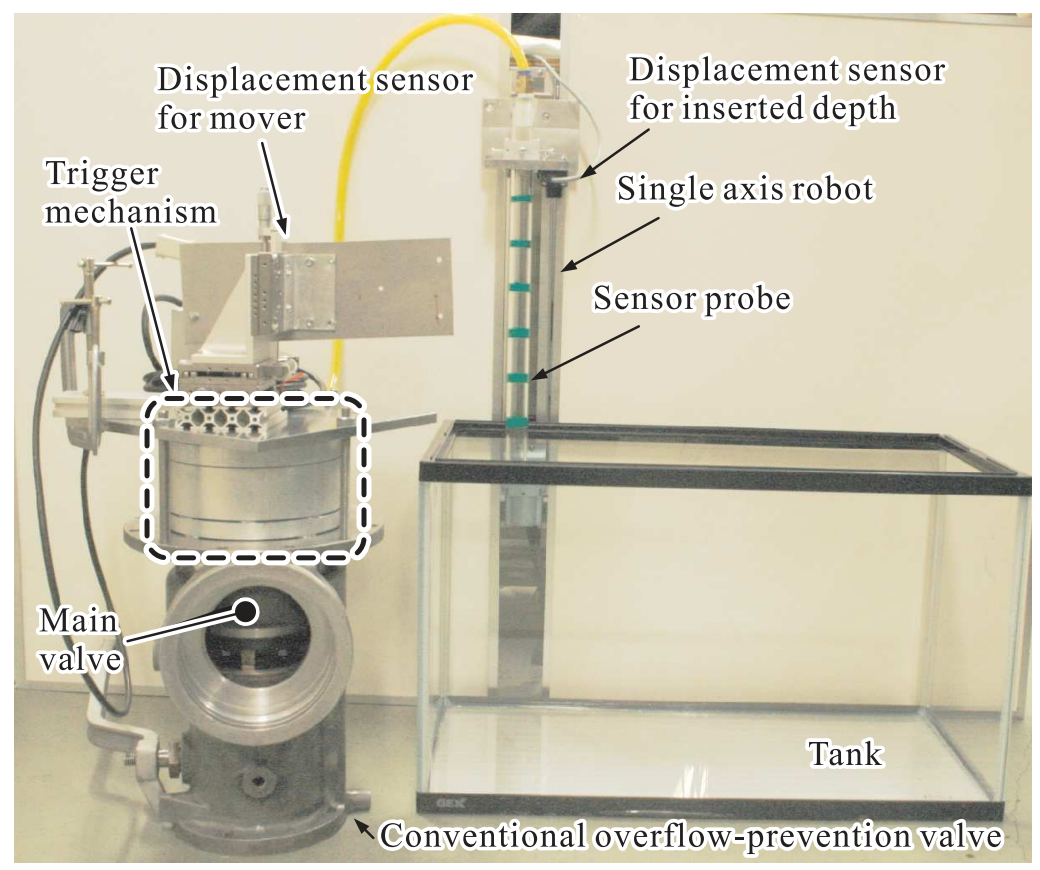

Fig. 12 Phtograph of an experimental setup. The main valve and the locking unit were used in the conventional overflow-prevention valve. The fabricated trigger mechanism is mounted on the conventional valve. The displacement of the mover is measured by the external displacement sensor. The sensor probe is attached to a single-axis robot with a level sensor for measuring the fluid level. The inserted depth and the velocity of the sensor probe are varied by a single-axis robot Water is used instead of oil for safety and the simplification of experiment. 
より，細いセンサプローブ(直径 $19[\mathrm{~mm}])$ で，かつ浅い挿入深さ(約 150[mm])でも，ロック機構を解除し，主弁に よって流路を閉じることを可能とした.

\section{謝 辞}

本論文をまとめるに当たり, 油機工業株式会社, 本学卒業生の千田竜太郎氏，黒籔弘大氏には多大なるご助力 をいただきました，期して深謝いたします。

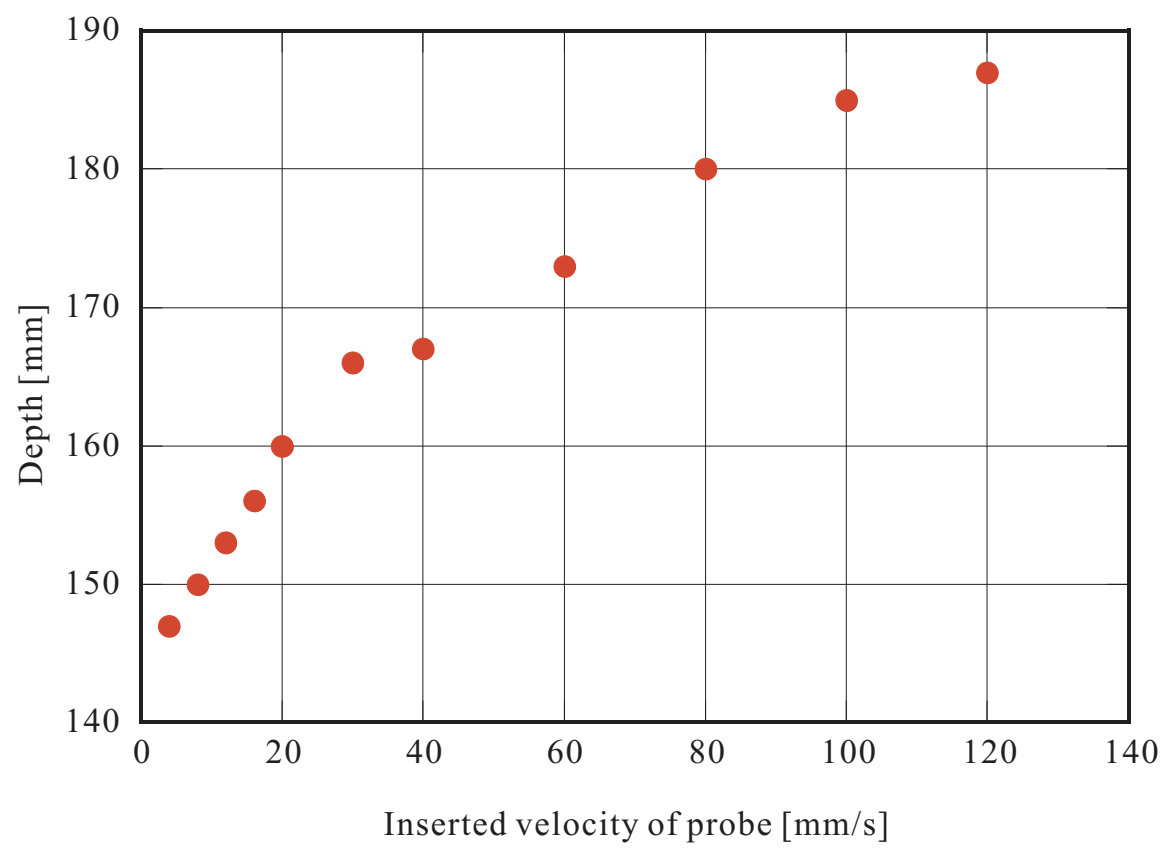

Fig. 13 Relation between the inserted velocity and the depth of the sensor probe. It is verified that the main valve is closed when the sensor probe is inserted into water at a depth of approximately $150[\mathrm{~mm}]$ at low inserted velocities. The inserted depth is expected to be approximately $180[\mathrm{~mm}]$ when oil is used. This result agrees with the previous analysis.

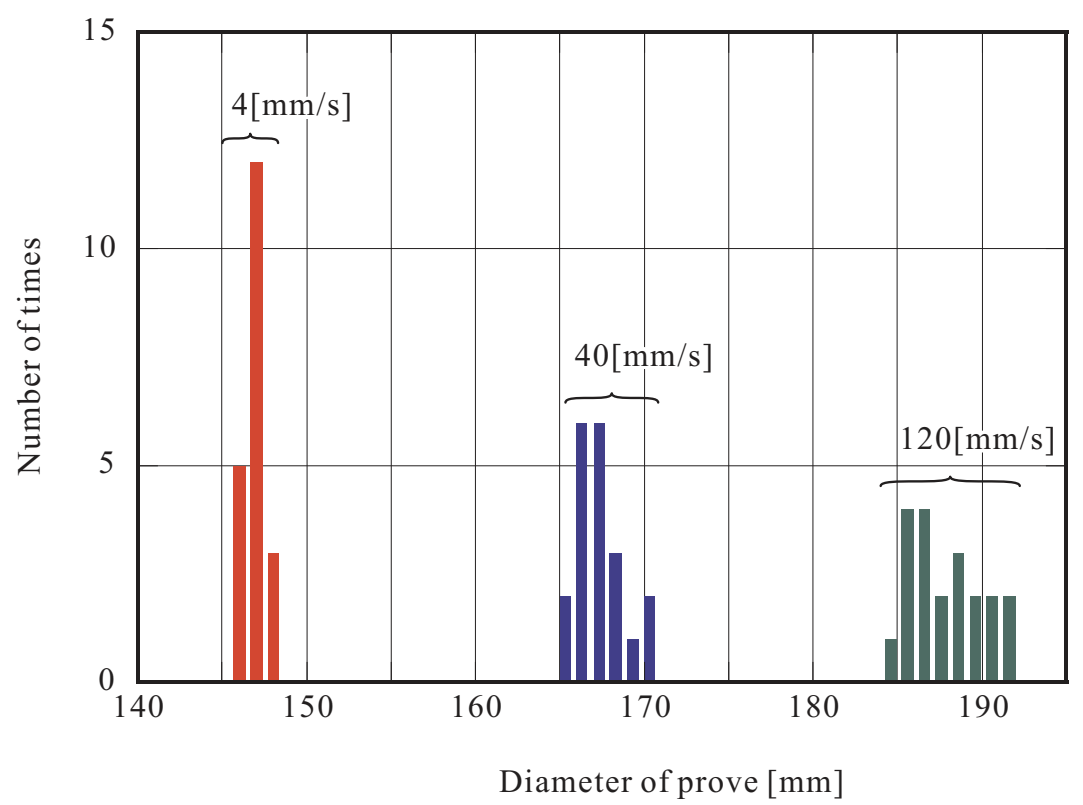

Fig. 14 Distribution of the inserted depth. The red, blue and green bars represent the numbers when the inserted velocity is $4[\mathrm{~mm} / \mathrm{s}]$, $40[\mathrm{~mm} / \mathrm{s}]$ and $120[\mathrm{~mm} / \mathrm{s}]$, respectively. 


\section{文献}

千田 竜太郎, 水野 毅, 高崎 正也, 石野 裕二, 永久磁石の横ずれ力を利用したオーバーフロー防止弁の開発, 第 58 回自動制御連合講演会論文集, 112-5, (2016).

Ishino, Y., Mizuno, T. and Takasaki, M., Development of overflow-prevention valve with trigger mechanism., Proc. the 13th International Conference on Motion and Vibration Control and the 12th International Conference on Recent Advances in Structural Dynamics (MoViC and RASID 2016), 2325, (2016).

木下利貞, 東邦石油尾熟工場 の港湾荷役設備, 燃料協会誌, Vol.44, No.2 (1965),p.96-105.

Klinkenberg, A. and Minne, J. L. van der, Electrostatics in the petroleum industry, Elserier Publishing Co. (1957).

水野毅, 石野裕二, 前場照玉, オーバーフロー防止弁, 特開 2014-224551, (2014).

油機工業株式会社, Engineered Fluid Handling Equipment, available from < http://www.yuki-kogyo.co.jp/ loadingsystem.html>, (参照日 2016 年 3 月 10 日).

\section{References}

Chida, R., Mizuno, T., Takasaki, M. and Ishino, Y., Development of overflow-prevention valve using lateral force between permanent magnets, 58th Proceedings of the Joint Automatic Control Conference, 1I2-5, (2016) (in Japanese).

Ishino, Y., Mizuno, T. and Takasaki, M., Development of overflow-prevention valve with trigger mechanism., Proc. the 13th International Conference on Motion and Vibration Control and the 12th International Conference on Recent Advances in Structural Dynamics (MoViC and RASID 2016), 2325, (2016).

Kinoshita, T., Cargo-working facilities at owase works, Journal of the Fuel Society of Japan, Vol. 44, No.2 (1965), p.96-105 (in Japanese).

Klinkenberg , A. and Minne, J. L. van der, Electrostatics in the petroleum industry, Elserier Publishing Co. (1957).

Mizuno, T., Ishino, Y. and Maeba, T., Overflow-prevention valve, Japanese patent disclosure, 2014-224551, (2014).

Yuki-kogyo Engineered Fluid Handling Equipment, available from <http://www.yuki-kogyo.co.jp/loadingsystem.html>, (accessed on 10, March, 2016) (in Japanese). 